\title{
Bamboo Wear and Its Application in Friction Material
}

\author{
Yunhai Ma, Yucheng Liu and Jin Tong \\ Additional information is available at the end of the chapter
}

http://dx.doi.org/10.5772/intechopen.69893

\begin{abstract}
Sliding wear behaviour of bamboo (Phyllostachys pubescens) was investigated in the cases of dry friction. The wear volume of bamboo was a function of the sliding velocity, the normal load and the relative orientation of bamboo fibres with respect to the friction surface. And tribological properties of the Bamboo Fiber Reinforced Friction Materials (BFRFMs) were tested on a constant speed friction tester. The results showed that the wear volume increased with the increase of sliding velocity and normal load. The normal-oriented specimens (N-type) showed sound wear resistance in comparison to the parallel-oriented ones $\left(\mathrm{P}_{\mathrm{S}}\right.$-and $\mathrm{P}_{\mathrm{I}}$-type), and the outside surface layer $\left(\mathrm{P}_{\mathrm{S}}\right.$-type $)$ showed sound resistance in comparison to the inner later ( $\mathrm{P}_{1}$-typ). The friction coefficient of BFRFMs (reinforced with $3 \mathrm{wt} . \%, 6 \mathrm{wt} . \%$ and $9 \mathrm{wt} . \%$ bamboo fibers) were higher than those of the non-bamboo fiber reinforced friction material with identical ingredients mixed with and process conditions during the temperature-increasing procedure. The friction coefficients of the specimens containing $3 \mathrm{wt}$ \% bamboo fibers were higher than that of other specimens. The wear rate of BFRFMs increased with the increasing of test temperature, and the wear rates of specimens containing $3 \mathrm{wt}$.\% bamboo fibers were lower than that of others specimens.
\end{abstract}

Keywords: bamboo, sliding wear, bamboo fiber, friction material, friction, wear

\section{Introduction}

Bamboo is a natural biomaterial and consists of vascular bundles (cellulose fibers). The vascular bundles are composed of many right-handed spiral phloem fibers at a certain spiral angle. Lakkad and Patel [1] investigated the mechanical properties of bamboo specimen, such as, Young's modulus, tensile strength, compressive strength, and interlaminar shear along 
fibers and the tensile strength across fibers. Bamboo has higher specific tensile strength than glass-reinforced plastic (GRP) and mild steel with chopped strand mat and woven roving, and comparable specific modulus with mild steel and GRP. Godbole and Lakkad [2] studied the influences of water absorption on mechanical performances of bamboo. The tensile strength, compressive strength, tensile modulus, and interlaminar shear of bamboo specimen reduced after soaking or boiling in distilled water. Li et al. [3] designed a double-fold spiral bionic composite model imitating the characteristic structure of bamboo. The tensile strength of carbon fiber reinforced tin composites processed by the bionic model was higher by $40 \%$ than that of unidirectional carbon fiber reinforced ones.

Yakou and Sakamoto [4] investigated abrasive performances of bamboo specimen with carborundum paper as the counterface. They indicated that the abrasive wear rate of the inner layer was higher than that of the outside surface layer for bamboo specimens of normal- and parallel-oriented cellulose fibers relative to the friction surface. Tong et al. [5] evaluated the abrasive wear properties of bamboo specimens by using quartz sand particles as abrasive material. The results showed that the abrasion resistance of bamboo specimen was decided by the relative orientation of the cellulose fibers with respect to the friction surface and by the size of abrasive particles. The abrasive wear rate increased with the increase of size of abrasive particles. Specimens with the normal orientation of cellulose fibers to the friction surface presented better abrasion resistance than those with the parallel orientation; the inner layer had lower abrasion resistance than the outside layer; and the cellulose fibers had better resistance than the matrix tissue. The dry sliding wear behavior of bamboo was studied in order to obtain some useful information for designs of friction materials.

On the other hand, friction materials are the key parts of automobiles brake systems, and many studies have been investigated to improve brake properties in order to adapt the people's requirement for security and rapid development of automobile [6]. To acquire comfortable and dependable brake properties of the automobiles, braking friction materials usually contain more than 10 different components. The components are normally classified as reinforced fibers, binders, property modifiers, and fillers. Each component plays an important role for brake performance under different braking conditions. Many studies investigated the effect of different components on brake performance [7, 8]. A related review on frontiers of fundamental tribological research emphasized the concern over the environmental protection, for instance, biodegradability in the development of tribo-materials [9].

Asbestos fibers, which have been widely used in braking friction materials, are harmful to human health and environment; they have been forbidden to be used for manufacturing friction materials. Therefore, substitutes of the asbestos fibers, such as steel fibers, $\mathrm{Al}_{2} \mathrm{O}_{3}$ fibers, carbon fibers, glass fibers, aramid fibers, copper fibers, and their hybrid fibers [10-12] have been studied and selected. Moreover, many study results showed that these fibers have excellent properties for friction materials; however, there are many shortcomings (such as weak combination strength, high cost, and high noise) to be resolved when these fibers are applied in friction materials.

Many researches have focused on the utilization of biological fibers with the function of protecting environment, such as betel nut fibers [13], cotton fibers [14, 15], jute fibers [16-18], kenaf and ramie fibers [19], sisal and flax fibers [20-22], and sugarcane fibers [23]. More and 
more biological fiber reinforced composite materials have been used as tribological ones. Dimensions and orientation of fibers in friction materials are important factors affecting its tribological properties. Such natural biomaterials with composite structures as bamboo provide clues and ideas for designs of friction materials, for example, antifriction materials and wear-resistant materials. The excellent structure of bamboo fiber was investigated by Paramesaran and Liese [24]. Bamboo fibers were used as one of the components in friction materials because of their low density and excellent mechanical properties in comparison to that of glass fibers [25-27]. Meanwhile, the bamboo fiber is a kind of plant fiber with cellulose structure and vascular bundles consisting of the fiber bundle and sclerenchyma sheaths.

In the present study, sliding wear behavior of bamboo (Phyllostachys pubescens) against a gray iron (HT200) was investigated in the cases of dry friction. The wear volume of bamboo was a function of the sliding velocity, the normal load, and the relative orientation of bamboo fibers with respect to the friction surface. Moreover, the mechanical and physical properties of the bamboo fibers were studied. Comparative studies were performed to investigate the effects of bamboo fiber content on the friction performances of friction materials. The tribological property of the friction materials was evaluated and discussed at the test temperature of $100-350^{\circ} \mathrm{C}$. The wear surface morphologies and the wear mechanism of bamboo fiber reinforced friction materials (BFRFMs) were analyzed using scanning electron microscopy (SEM).

\section{Experimental materials and methods}

\subsection{Bamboo wear experiments}

Bamboo specimens of dimensions $14 \times 10 \times 8 \mathrm{~mm}$ were cut from the air-dry bamboo (P. pubescens). Three types of specimens were prepared. The friction surface was normal to the cellulose fiber orientation for the N-type, and parallel to both the cellulose fiber orientation and the outside surface of bamboo stem for the $\mathrm{P}_{\mathrm{S}}$-type and $\mathrm{P}_{\mathrm{I}}$-type. The initial rubbing surface was $0.5 \mathrm{~mm}$ beneath the natural surface for the $\mathrm{P}_{\mathrm{S}}$-type and $8.5 \mathrm{~mm}$ for $\mathrm{P}_{\mathrm{I}}$-type. Figure 1 shows the fiber orientation with the sliding direction.

Sliding wear properties of bamboo specimens were studied on a block-on-ring machine. The counterfaces were made of a gray iron (HT200) and had a diameter of $40 \mathrm{~mm}$. The normal loads were from 30 to $120 \mathrm{~N}$ and the sliding velocity was set as 0.42 and $0.84 \mathrm{~m} \mathrm{~s}^{-1}$, respectively; the total sliding distance was about $504 \mathrm{~m}$ and the surrounding temperature was about $23^{\circ} \mathrm{C}$ during all these tests. Worn morphologies of bamboo specimens and gray iron rings and wear debris were examined by SEM and stereoscopy.

\subsection{Preparation of bamboo fiber specimens}

Bamboos possess the excellent wear properties, and in present paper, bamboo fibers are selected as the reinforced fibers. The fresh bamboo (Phyllostachys heterocycla) was first cut into pieces after removing the outer and inner surface materials. The bamboo pieces were 


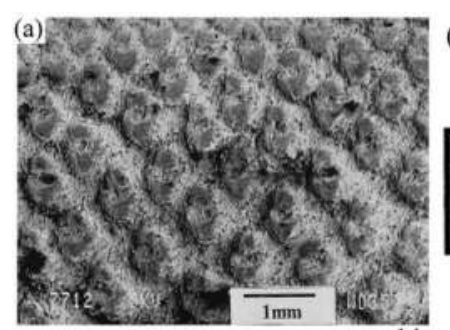

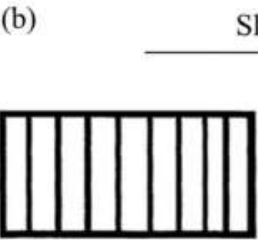

N-type
Sliding direction

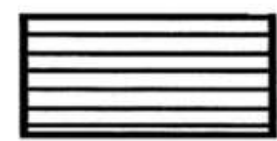

P-type

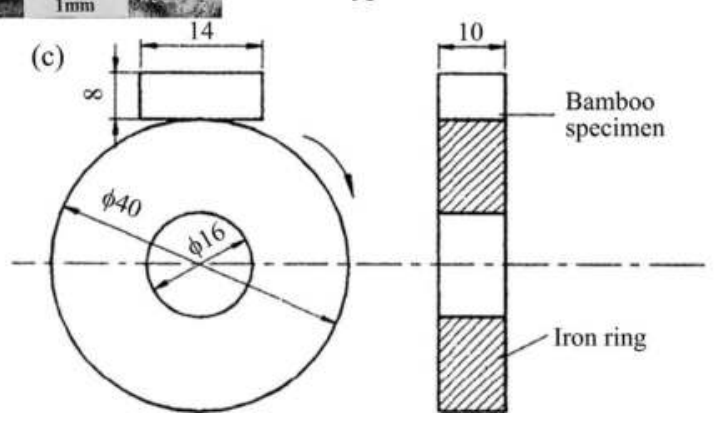

Figure 1. (a) A photograph showing section structure of bamboo stem shell; (b) schematic diagram showing fiber orientation with respect to the rubbing surface for the $\mathrm{N}$ and $\mathrm{P}\left(\mathrm{P}_{\mathrm{S}}\right.$ and $\left.\mathrm{P}_{\mathrm{I}}\right)$ specimens; and (c) the contract model of block-on-ring wear.

immersed into the softener solution $\left(2 \%\right.$ vol $\mathrm{NH}_{3} \cdot \mathrm{H}_{2} \mathrm{O}, 4 \%$ vol $\left.\mathrm{CON}_{2} \mathrm{H}_{4}\right)$ and boiled for $1 \mathrm{~h}$ at $100^{\circ} \mathrm{C}$. Then these pieces were kept in $\mathrm{NaOH}(4 \% \mathrm{vol})$ solution for $30 \mathrm{~min}$ at $70^{\circ} \mathrm{C}$. The pieces with softened fibers were broken mechanically and carded into fiber bundle. Finally, the fibers were dried in an oven at $60^{\circ} \mathrm{C}$ for $30 \mathrm{~min}$. Every specimens of the bamboo fiber were $40 \mathrm{~mm}$ (for tensile test) or 3-5 $\mathrm{mm}$ in length and 1-3 $\mathrm{mm}$ in diameter. The diameters of bamboo fibers were measured and marked using a stereo microscope, which has a precision of $0.01 \mu \mathrm{m}$.

\subsection{Mechanical testing of the bamboo fiber}

The mechanical properties of the bamboo fibers were evaluated by tensile testing machine. The specimens of the bamboo fibers for tensile tests were $40 \mathrm{~mm}$ in length and $0.5 \pm 0.05 \mathrm{~mm}$ in diameter. The tensile speed was $100 \mathrm{~mm} \mathrm{~min}^{-1}$ referring to the pulling speed of the tensile test machine during test. Ten tests were run for each bamboo fiber. The elongation at fracture, tensile strength, and elastic modulus of the fiber were recorded.

The raw components used for preparing the friction materials are listed in Table 1. Phenolic resin was used as adhesive; powders (such as $\mathrm{Al}_{2} \mathrm{O}_{3}, \mathrm{Sb}_{2} \mathrm{~S}$, graphite) were used as fillers. The mass fraction of the bamboo fibers added in the friction materials was $0,3,6,9$, and $12 \mathrm{wt} . \%$, respectively. All raw components were mixed using a blender for $10 \mathrm{~min}$. The mixed materials were blocked with the dimension of $25 \times 25 \times 6 \mathrm{~mm}$ by compression molder equipment for $30 \mathrm{~min}$ at $165^{\circ} \mathrm{C}$ under pressure of $25 \mathrm{MPa}$, followed by heat treatment. The posttreating was segmented at $140^{\circ} \mathrm{C}$ for $1 \mathrm{~h}, 150^{\circ} \mathrm{C}$ for $3 \mathrm{~h}$, and $180^{\circ} \mathrm{C}$ for $6 \mathrm{~h}$ continually as shown in Figure 2. 


\begin{tabular}{|c|c|c|c|c|c|}
\hline \multirow[t]{2}{*}{ Raw ingredients } & \multicolumn{5}{|c|}{ Bamboo fiber content (wt. \%) } \\
\hline & 0 & 3 & 6 & 9 & 12 \\
\hline Mineral fiber & 17 & 16.5 & 16.04 & 15.6 & 15.18 \\
\hline Glass fiber & 10 & 9.71 & 9.43 & 9.17 & 8.93 \\
\hline Phenolic resin & 13 & 12.62 & 12.26 & 11.93 & 11.61 \\
\hline $\begin{array}{l}\text { Vermiculite } \\
\text { powder }\end{array}$ & 5 & 4.85 & 4.72 & 4.59 & 4.46 \\
\hline $\begin{array}{l}\text { Foam iron } \\
\text { powder }\end{array}$ & 11 & 10.68 & 10.38 & 10.09 & 9.82 \\
\hline $\mathrm{BaSO}_{4}$ & 20 & 17.47 & 16.98 & 16.51 & 15.57 \\
\hline Petroleum coke & 6 & 5.81 & 5.66 & 5.5 & 5.36 \\
\hline Graphite & 8 & 7.76 & 7.55 & 7.34 & 7.14 \\
\hline $\mathrm{Al}_{2} \mathrm{O}_{3}$ & 4 & 3.88 & 3.77 & 3.69 & 3.57 \\
\hline $\mathrm{Sb}_{2} \mathrm{~S}_{3}$ & 3 & 2.91 & 2.83 & 2.75 & 2.68 \\
\hline Friction powder & 1 & 0.97 & 0.94 & 0.92 & 0.89 \\
\hline Zinc stearate & 2 & 1.94 & 1.89 & 1.83 & 1.79 \\
\hline Carbon black & 3 & 1.9 & 1.1 & 1.08 & 1 \\
\hline
\end{tabular}

Table 1. Relative contents of raw ingredients in the designed specimens of friction materials.

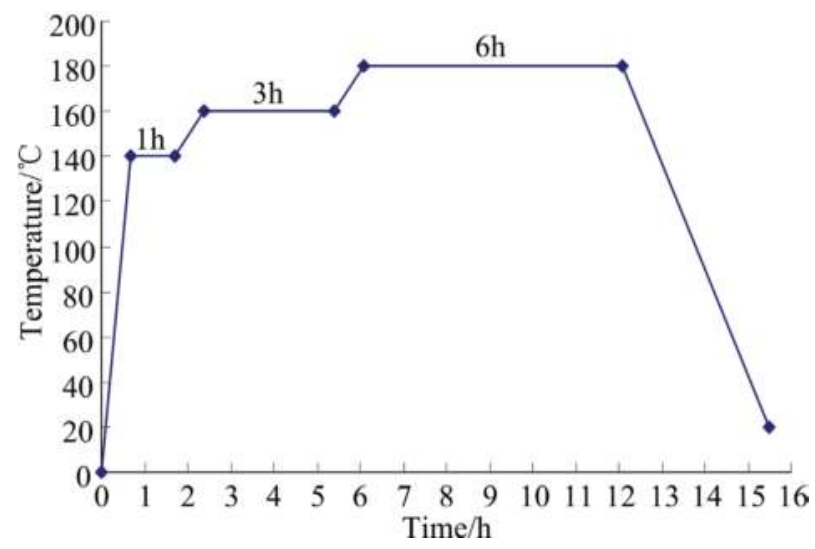

Figure 2. Heating process for preparation of friction materials.

\subsection{Friction and wear tests}

The tribological property of friction materials was investigated using a constant speed friction tester with speed of $7.54 \mathrm{~m} \mathrm{~s}^{-1}$ under pressure of $0.98 \mathrm{MPa}$. The rotating disc (HT250 cast iron) was used as the counterpart. Friction and wear tests were implemented at the test temperature of $100,150,200,250,300$, and $350^{\circ} \mathrm{C}$, respectively [28]. The friction coefficients $\left(\mu_{I}(i)\right)$ (under the 
temperature-increasing condition) were automatically recoded. The friction coefficients $\left(\mu_{I}(i)\right.$, $\left.\mu_{D}(i)\right)$, and specific wear rate $(V(i))$ were obtained after 5000 rotations of the disc, where $i=1,2$, $\ldots, 6$, corresponding to the temperature of $100,150,200,250,300$, and $350^{\circ} \mathrm{C}$, respectively. The volume wear rate of the friction materials was evaluated and calculated as follows:

$$
V(t)=\frac{1}{2 \pi R} \frac{A}{n} \frac{d_{1}-d_{2}}{f_{m}}
$$

where $n$ is the number of revolutions of the disk $(n=5000), R$ is the distance between the center of the rotating disk and friction material specimen $(R=0.15 \mathrm{~m}), A$ is the contact surface between the specimen and the $\operatorname{disk}\left(A=625 \mathrm{~m}^{2}\right), d_{1}$ is the average thickness of specimen before test $(\mathrm{mm})$, $d_{2}$ is the average thickness of specimen after test $(\mathrm{mm})$, and $f_{m}$ is mean value of the force.

Worn morphologies of the specimens after tests were observed using the SEM (JEOL JSM5600 ) at a voltage of $25 \mathrm{kV}$.

\section{Experimental results and discussion}

\subsection{Wear tests of bamboo specimens}

Figure 3 illustrates the wear volume of the three types of bamboo specimens versus the normal load at 0.42 and $0.84 \mathrm{~m} \mathrm{~s}^{-1}$. It can be seen from Figure 3 that the wear volume was dependent upon the normal load, the sliding velocity, and the relative orientation of bamboo fibers with respect to the friction surface. The wear volume and its difference between different types of specimens increased with the increase of normal load. The wear rate at $0.42 \mathrm{~m} \mathrm{~s}^{-1}$ velocity was lower than that at $0.84 \mathrm{~m} \mathrm{~s}^{-1}$. The $\mathrm{N}$-type specimens presented excellent wear resistance. Although they had the same relative orientation of friction surface, $\mathrm{P}_{\mathrm{S}}$-type specimens presented better wear resistance than $\mathrm{P}_{\mathrm{I}}$-type specimens under identical experimental conditions, suggesting that the wear resistance of the outside layer of bamboo stem was higher than that of its inner layer.

\subsection{Wear track morphologies of gray iron rings}

The materials transfer from the bamboo specimens to the iron surface occurred due to adhesion. In the initial stage, transferred material formed some patches on the gray iron ring surface, as shown in Figure 4a. As the sliding distance was increased, transferred material patches were extended along the sliding direction because of crushing action and further adhesion. When the interfacial contact reached a steady state, the adhesion transfer film was in a relatively steady state as shown in Figure $\mathbf{4 b}$. The transferred material film did not cover the entire friction surface of the iron ring, as the material transferred to the ring surfaces could be detached. This transferring-detaching process resulted in the adhesive wear of bamboo. Features of adhesive wear were also found on worn surfaces of bamboo specimens and will be discussed in the following sections. 

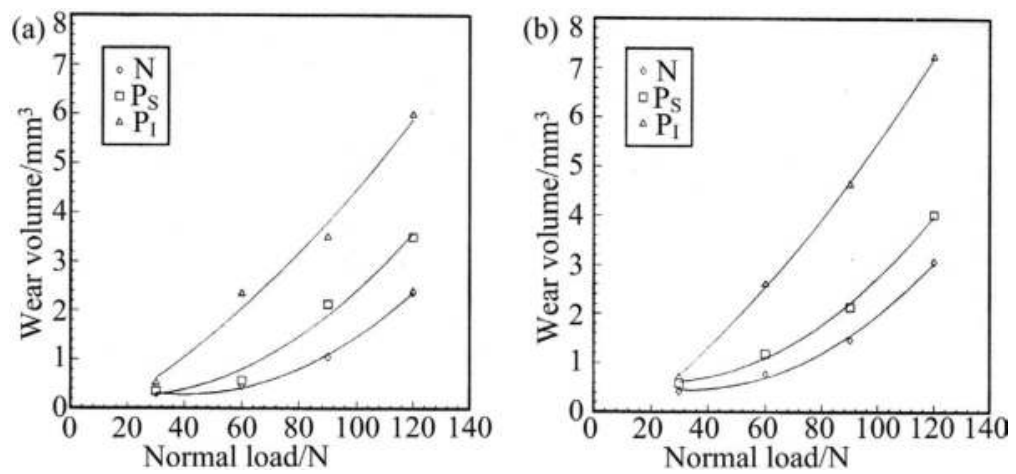

Figure 3. The wear volume of the three types of bamboo specimens versus the normal load at sliding velocity of (a) $0.42 \mathrm{~m} \mathrm{~s}^{-1}$ and (b) $0.84 \mathrm{~m} \mathrm{~s}^{-1}$.
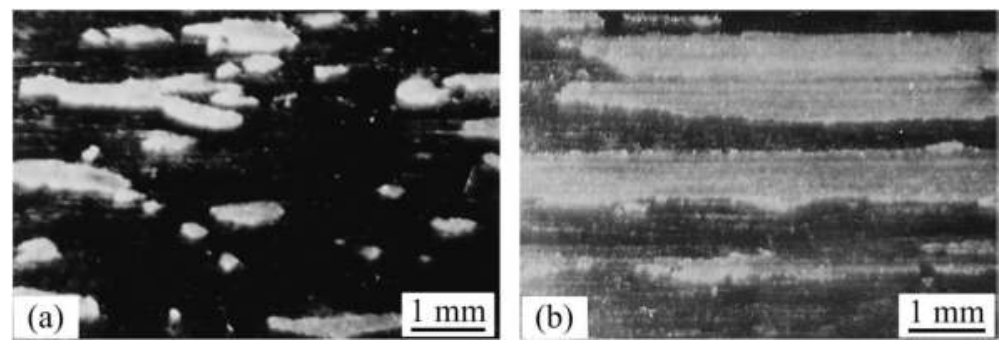

Figure 4. Stereographs of wear track of the gray iron ring.

\subsection{Wear of $P_{\mathrm{s}}$-type bamboo specimens}

Figure 5 illustrates typical morphologies of worn surfaces of $\mathrm{P}_{\mathrm{S}}$-type specimens. There were mainly three wear features: pits, microcracks, and grooves. Pits were produced because of adhesion between bamboo specimens and iron. Some materials from these pits were transferred onto the gray iron ring surface and the remainder became wear debris. Because of asperities of the gray iron ring surface, a tensile stress existed in the bamboo surface layer at the rear of the contacting asperity and a compressive stress at front. This stress distribution could easily lead to microcracking of the bamboo surface layer across the friction direction. Moreover, the adhesion force existing at the contacting interface strengthened this microcracking process. However, microcracks along the friction direction may be directly nucleated and propagated due to the tensile stress. As the normal load was raised, the influence of microploughing-microcutting on the wear of the bamboo specimens surface layer became stronger, and the microploughing-microcutting grooves on worn surfaces generated under $60-90 \mathrm{~N}$ load at $0.42 \mathrm{~m} \mathrm{~s}^{-1}$ velocity were shallow (Figure 5a-d). For this case, damage of cellulose fibers was not severe. However, when the normal load reached $120 \mathrm{~N}$, particularly at $0.84 \mathrm{~m} \mathrm{~s}^{-1}$ velocity, the cellulose fiber walls had been cut, but leptodermous 

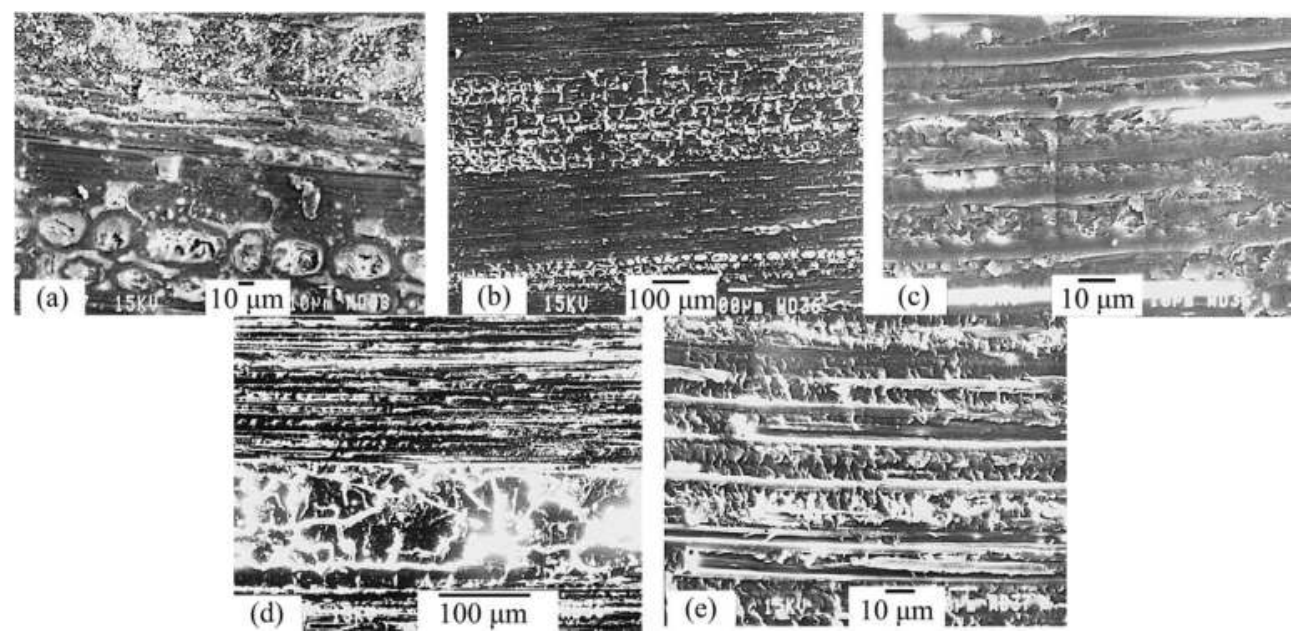

Figure 5. SEM micrographs of worn surfaces of $\mathrm{P}_{\mathrm{s}}$-type bamboo specimens. (a) $60 \mathrm{~N}, 0.42 \mathrm{~m} \mathrm{~s}^{-1}$; (b) $90 \mathrm{~N}, 0.42 \mathrm{~m} \mathrm{~s}^{-1}$; (c) details from (b); (d) $120 \mathrm{~N}, 0.42 \mathrm{~m} \mathrm{~s}^{-1}$; and (e) $120 \mathrm{~N}, 0.84 \mathrm{~m} \mathrm{~s}^{-1}$.

cell tissue between the cellulose fibers and the material inside vascular bundles were not completely removed (Figure 5e).

It can be considered from the surface morphology shown in Figure 5 that adhesion, microcracking, and microploughing-microcutting were the main wear mechanisms of $\mathrm{P}_{\mathrm{s}}$-type bamboo specimens. When the normal load and sliding velocity were low, the adhesive wear, microcracking, and microploughing were predominant, while, when the load and velocity were high, the predominant wear mechanism was microploughing-microcutting.

\subsection{Wear of $P_{\mathrm{I}}$-type bamboo specimens}

Figure 6 illustrates typical morphologies of worn surfaces of $\mathrm{P}_{\mathrm{I}}$-type bamboo specimens. It was seen that microcracks and microploughing grooves existed on the worn surfaces at low magnification, as shown in Figure $\mathbf{6 a}$ and e. Figure $\mathbf{6 c}$ shows some extent of the adhesive wear. At high magnification, besides some microcracks with random distribution illustrated in Figure 6a, some regular microcracking took place, as shown in Figure $6 \mathbf{c}$ and e. The regular microcracking under low load mainly displayed two states. One was local microcracking, causing some strips of bamboo material to be dug out from the surface layer, as shown in Figure $\mathbf{6 b}$. Another was microcracking along the fiber direction (i.e., the rubbing direction) and then across fiber direction, as shown in Figure 6e. The tensile and compressive stresses of the bamboo surface layer under the contacting asperities of the ring surface and the adhesion force between both rubbing surfaces played important roles in the surface microcracking during the rubbing process. Generally, the former regular-microcracking occurred at the lower velocity $\left(0.42 \mathrm{~m} \mathrm{~s}^{-1}\right)$ and the latter took place at the higher velocity $\left(0.84 \mathrm{~m} \mathrm{~s}^{-1}\right)$. Compared with $\mathrm{P}_{\mathrm{S}}$-type, $\mathrm{P}_{\mathrm{I}}$-type specimens were severely ploughed, as shown in Figure $6 \mathbf{b}$ and $\mathbf{d}$. When the load was increased to $120 \mathrm{~N}$, particularly at high velocity $\left(0.84 \mathrm{~m} \mathrm{~s}^{-1}\right)$, 

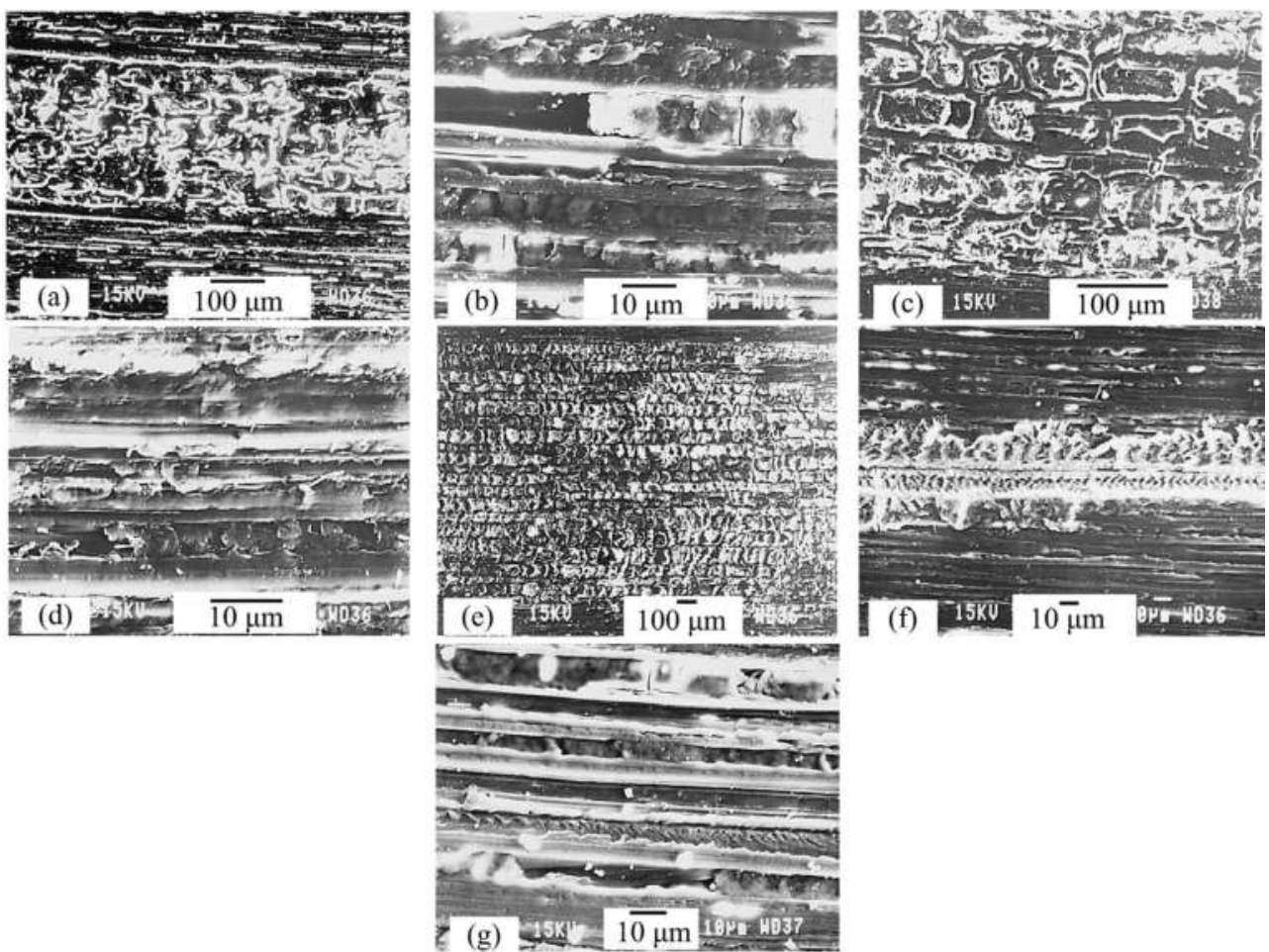

Figure 6. Worn surface micrographs of $\mathrm{P}_{\mathrm{I}}$-type bamboo specimens. (a) $60 \mathrm{~N}, 0.42 \mathrm{~m} \mathrm{~s}^{-1}$; (b) details of ploughing grooves in (a); (c) $60 \mathrm{~N}, 0.42 \mathrm{~m} \mathrm{~s}^{-1}$; (d) $90 \mathrm{~N}, 0.42 \mathrm{~m} \mathrm{~s}^{-1}$; (e) $60 \mathrm{~N}, 0.84 \mathrm{~m} \mathrm{~s}^{-1}$; (f) and (g) $120 \mathrm{~N}, 0.84 \mathrm{~m} \mathrm{~s}^{-1}$.

asperities of the ring surface cut into the $\mathrm{P}_{\mathrm{I}}$-type specimen surface layer and ploughed up the middle texture material of vascular bundles (see Figure $6 f$ ), or very deep grooves were produced (see Figure 6g). These topographies represented severe wear rupture of $\mathrm{P}_{\mathrm{I}}$-type specimens. Comparing the morphologies illustrated in Figures 5 and 6, it was found that the microploughing-microcutting damage of $\mathrm{P}_{\mathrm{I}}$-type specimens was larger than that of $\mathrm{P}_{\mathrm{S}}$-type specimens under identical experimental conditions. The main wear mechanisms of $\mathrm{P}_{\mathrm{I}}$-type bamboo specimens were also adhesion, specially, microcracking and microploughing-microcutting. The degree of damage of $\mathrm{P}_{\mathrm{I}}$-type specimens was severe in comparison to that of $\mathrm{P}_{\mathrm{S}}-$ type ones.

\subsection{Wear of N-type bamboo specimens}

Figure 7 illustrates typical morphologies of worn surfaces of the N-type bamboo specimens. The structure of the bamboo stem was basically revealed at low magnification, as shown in Figure 7a, $\mathbf{d}, \mathbf{g}$, and $\mathbf{h}$. The larger dark zones are the ends of vascular bundles consisting of several vascular, and the remainder is matrix tissue. It can be seen that there existed a certain difference in wear behavior between vascular bundles consisting of sclerenchyma cells and matrix tissue consisting 
of leptodermous cells. The wear rupture of vascular bundles was severe as compared with that of the matrix tissue. This result was opposite to the abrasive wear behavior of N-type specimens in free-abrasive wear conditions, in which the ends of vascular bundles were protruded on the matrix of the abrading surface of N-type specimens, suggesting that vascular bundles of bamboo possessed higher wear resistance than matrix tissue [5]. It was seen to the naked eye that the ends of vascular bundles were darker than matrix tissue after sliding friction, particularly at high velocity or under high load (see Figure $7 \mathbf{d}, \mathbf{e}, \mathbf{g}$, and $\mathbf{h}$ ). High temperature caused by frictional heat would burn the contacting bamboo surface. The vascular bundles were mainly burned for the $\mathrm{N}$-type. This phenomenon can be observed clearly after grinding a bamboo block (N-type mode) against an abrasive wheel. The burnt material may easily be removed by asperities of the ring surfaces. The interfacial temperature was dependent upon the normal load and, particularly, sliding velocity [29]. Therefore, topographies of the ends of vascular bundles of worn surfaces of N-type bamboo specimens varied with the load and velocity.

Figure $\mathbf{7 b}$ shows that the part surrounded by vascular of cellulose fibers (i.e., the center area of a vascular bundle) protruded. This was more obvious at low load and velocity (see Figure 7a
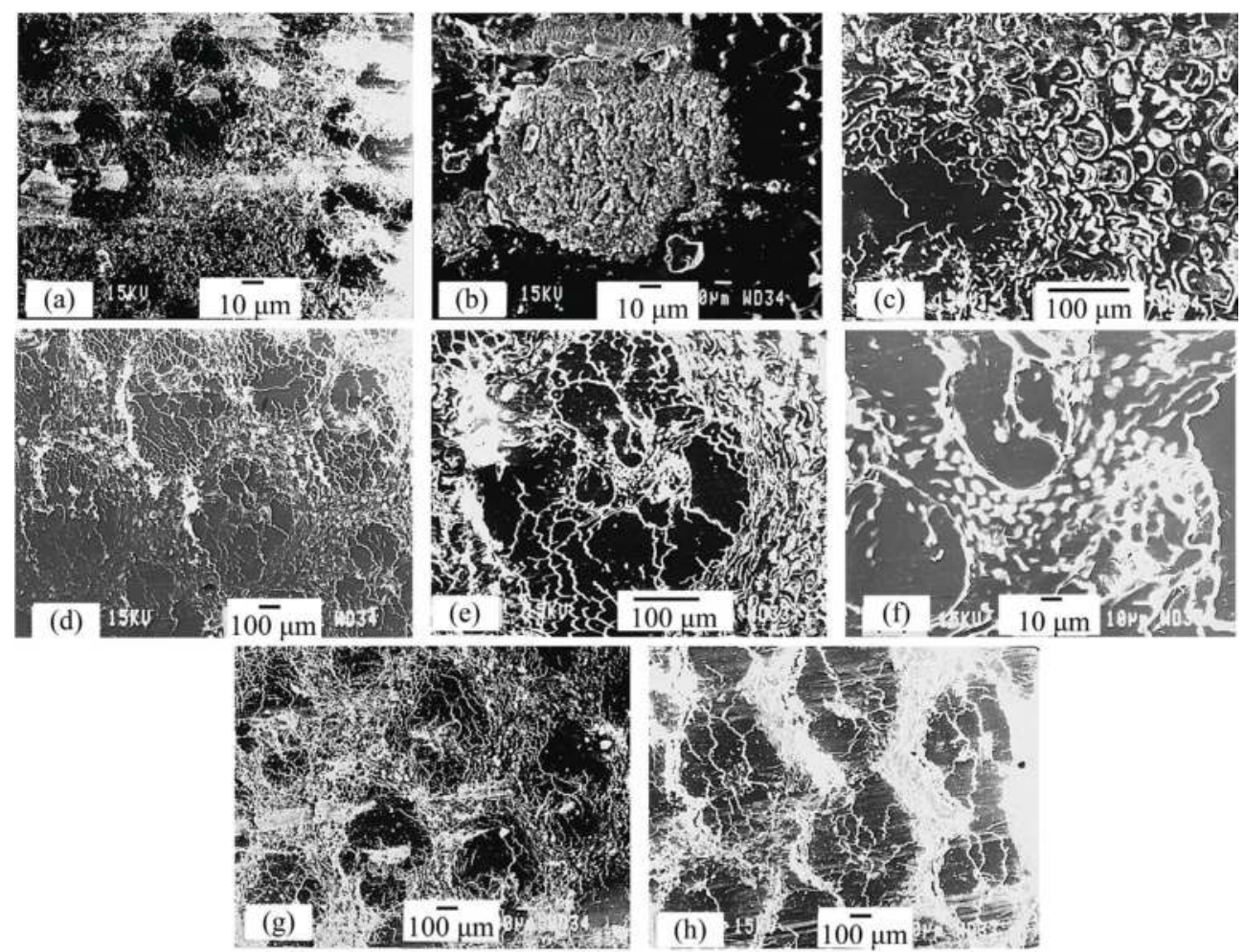

Figure 7. Worn surface micrographs of N-type bamboo specimens. (a) $60 \mathrm{~N}, 0.42 \mathrm{~m} \mathrm{~s}^{-1}$; (b) details of the center area of a vascular bundle in (a); (c) details of leptodermous cell of the lower area of (a); (d) $120 \mathrm{~N}, 0.42 \mathrm{~m} \mathrm{~s}^{-1}$; (e) details of a vascular bundle of the center area of (d); (f) details of the center area of the vascular bundle of (e); (g) $60 \mathrm{~N}, 0.84 \mathrm{~m} \mathrm{~s}^{-1}$; (h) $120 \mathrm{~N}$, $0.84 \mathrm{~m} \mathrm{~s}^{-1}$ (the friction direction of the ring was from left to right). 
and $\mathbf{b})$. As the load or velocity was increased, the area of the protruded part became smaller, comparing Figure $\mathbf{7 a}, \mathbf{d}, \mathbf{g}$, and $\mathbf{h}$. It was considered that the center part of a vascular bundle would have leptodermous cell texture because its tribological behavior was similar to that of matrix tissue. Figure $7 \mathrm{c}$ gives the details of the worn surface of matrix tissue.

Worn micrograph of N-type bamboo specimens mainly presented adhesive wear and microcracking. No microploughing-microcutting feature was observed on worn surfaces except those of $120 \mathrm{~N}$ load and $0.84 \mathrm{~m} \mathrm{~s}^{-1}$ velocity (Figure $7 \mathbf{h}$ ). Besides the microcracking of matrix tissue, cracking between bundles and matrix occurred, as shown in Figure $\mathbf{7 f}$ and $\mathbf{h}$.

\subsection{Mechanical and physical properties of bamboo fibers}

The mechanical and physical properties of bamboo fibers in this study are listed in Table 2. From Table 2, it can be seen that the elongation at fracture of alkaline-treated bamboo fibers was about $1.2 \%$, the tensile strength was about $56.3 \mathrm{MPa}$, and the elastic modulus was about 18.6 GPa. However, for untreated bamboo fibers, the elongation at fracture was $1.7 \%$, the tensile strength was $46.7 \mathrm{MPa}$, and the elastic modulus was $23.3 \mathrm{GPa}$. It indicated that the tensile strength and elastic modulus were increased by the modification of bamboo fibers. It is because the crystallinity of the alkaline-treated bamboo fiber was increased, which could improve the polarity of molecules and the adhesion strength between the high molecules. The slip produced by destruction of the binding force of molecules was relatively small, so the elongation at fracture was reduced, and the tensile strength and elastic modulus was increased after modification for bamboo fiber.

The stress-strain curve of the alkaline-treated bamboo fibers is shown in Figure 8. At the initial stage, the stress was proportional to the strain, which is consistent with the Hooke's Force Law. There was no yield and necking phenomenon, and the stress and strain were very low before breaking. It indicated that the bamboo fiber was a brittle material. The brake pads were basically acted by compression pressure when they work. Hence, the lower tensile strength of bamboo fiber does not have impact on the braking performance of brake pad.

It can be seen from Figure 9a that a major part of the fracture surfaces presented brittle failure. Some small molecule impurities on bamboo fiber surface were removed by the alkaline solution that caused the adhesion strength among fibers to be reduced considerably. The fracture of the untreated fiber (Figure 9b) showed that the uneven break presented because of the uneven stress that resulted from the bonding of pectin with lignin among the fibers.

The bamboo fibers connected with each other under pressure. The tangential resistance generated in relative sliding is called friction force. The tangential resistance is called cohesive force at the normal press of zero. Figure 10 shows that the bamboo fibers were assembled, entangled, bonded,

\begin{tabular}{llll}
\hline & Elongation (\%) & Tensile strength (MPa) & Elastic modulus (GPa) \\
\hline Untreated bamboo fiber & 1.7 & 46.7 & 18.6 \\
$\begin{array}{l}\text { Alkaline-treated bamboo } \\
\text { fiber }\end{array}$ & 1.2 & 56.3 & 23.3 \\
\hline
\end{tabular}

Table 2. Test results of mechanical properties of bamboo fiber. 


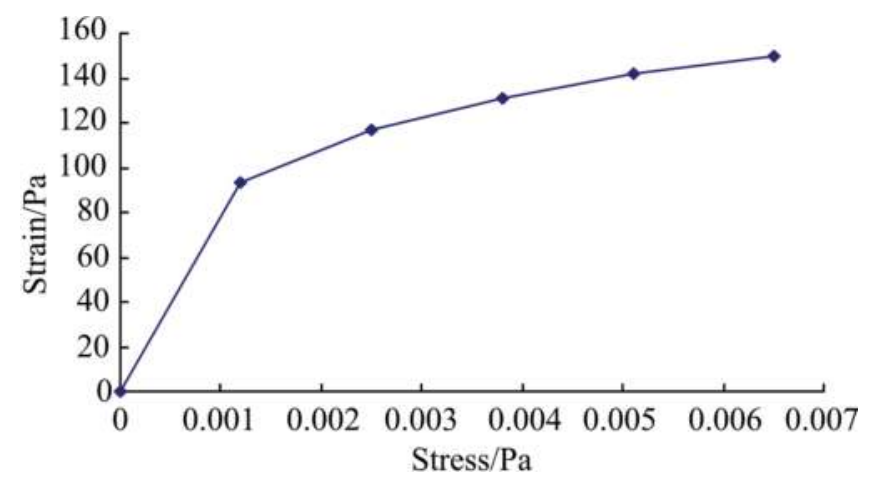

Figure 8. Test result of tensile stress-strain curve of a bamboo fiber treated with alkaline solution.

(a)

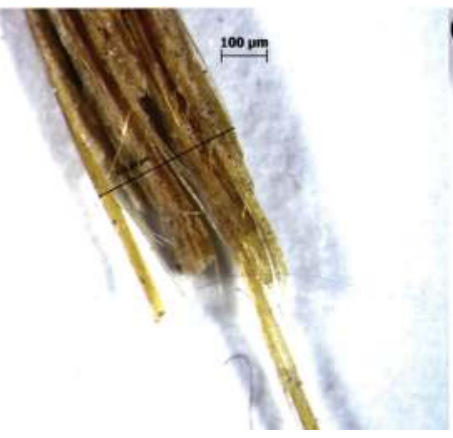

(b)

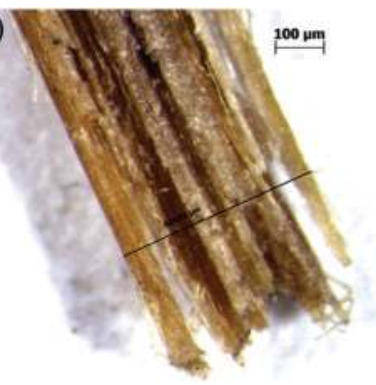

Figure 9. Morphologies of tensile fracture of (a) the bamboo fiber treated with alkaline solution; and (b) the untreated bamboo fiber.

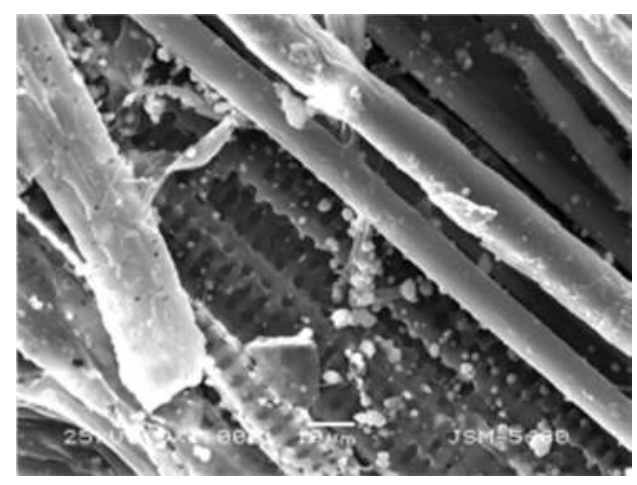

Figure 10. Bamboo fiber assemblies. 
and held tightly together due to the role of cohesive force that is not easy to loose. Therefore, the properties of the friction materials were affected by the friction force and the cohesive force.

\subsection{Effect of bamboo fiber on friction performance}

It can be found from Figure 11 that the friction coefficients of BFRFMs with 3, 6, and 9 wt.\% bamboo fibers were higher than those of the friction materials without bamboo fibers. The friction coefficients of the BFRFMs have significant variations at the test temperature of $250^{\circ} \mathrm{C}$. This is because phenolic resin began to pyrolyse, and the bamboo fibers were carbonized gradually when temperature exceeded $250^{\circ} \mathrm{C}$. However, the friction coefficient of BFRFMs containing $12 \mathrm{wt}$ \% bamboo fibers decreased with the increase of test temperature.

It can be seen from Figure 12 that wear rates of the BFRFMs generally increased with the increase of test temperature since the matrix began to soften, and the bamboo fibers were carbonized with the increase of test temperature. The surface roughness of friction materials containing 6, 9, and $12 \mathrm{wt} . \%$ bamboo fibers was high, so the adhesive wear and microcutting wear appeared on the worn surface. This is because the heat fading of the phenolic resin appeared, and the small hard particles formed from some glass fibers separated from the matrix. Plenty of wear debris formed and fell off, so the wear rate of friction materials significantly increased. The wear rate of friction materials containing $3 \mathrm{wt}$ \% bamboo fibers was the lowest. In fact, some voids and grooves formed after the carbonization of the bamboo fibers can contain some other abrasive particles.

\subsection{Wear surface morphologies of BFRFMs}

The worn surface morphologies of the BFRFMs are shown in Figure 13. It can be seen from Figure 13 that some glass fibers exposed and some did not separate from the matrix. The glass fibers and friction surfaces were supported by the matrix. Some hard particles from the glass

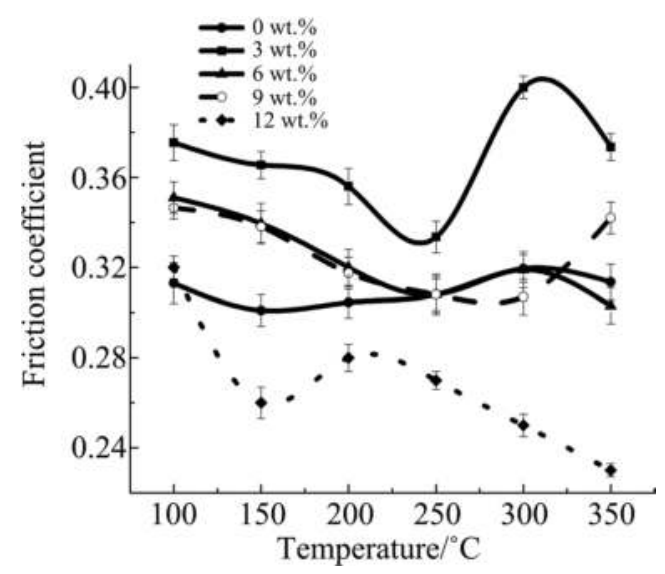

Figure 11. Variation of the friction coefficient of the bamboo fiber reinforced friction materials with the temperature. 


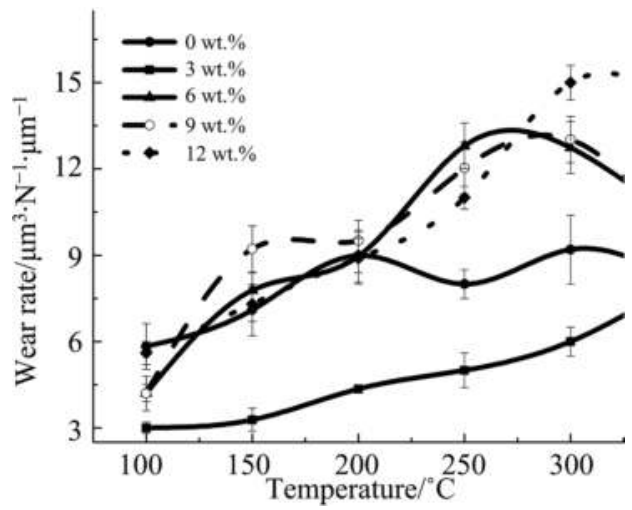

Figure 12. Variation of wear rate of the bamboo fiber reinforced friction materials with temperature.
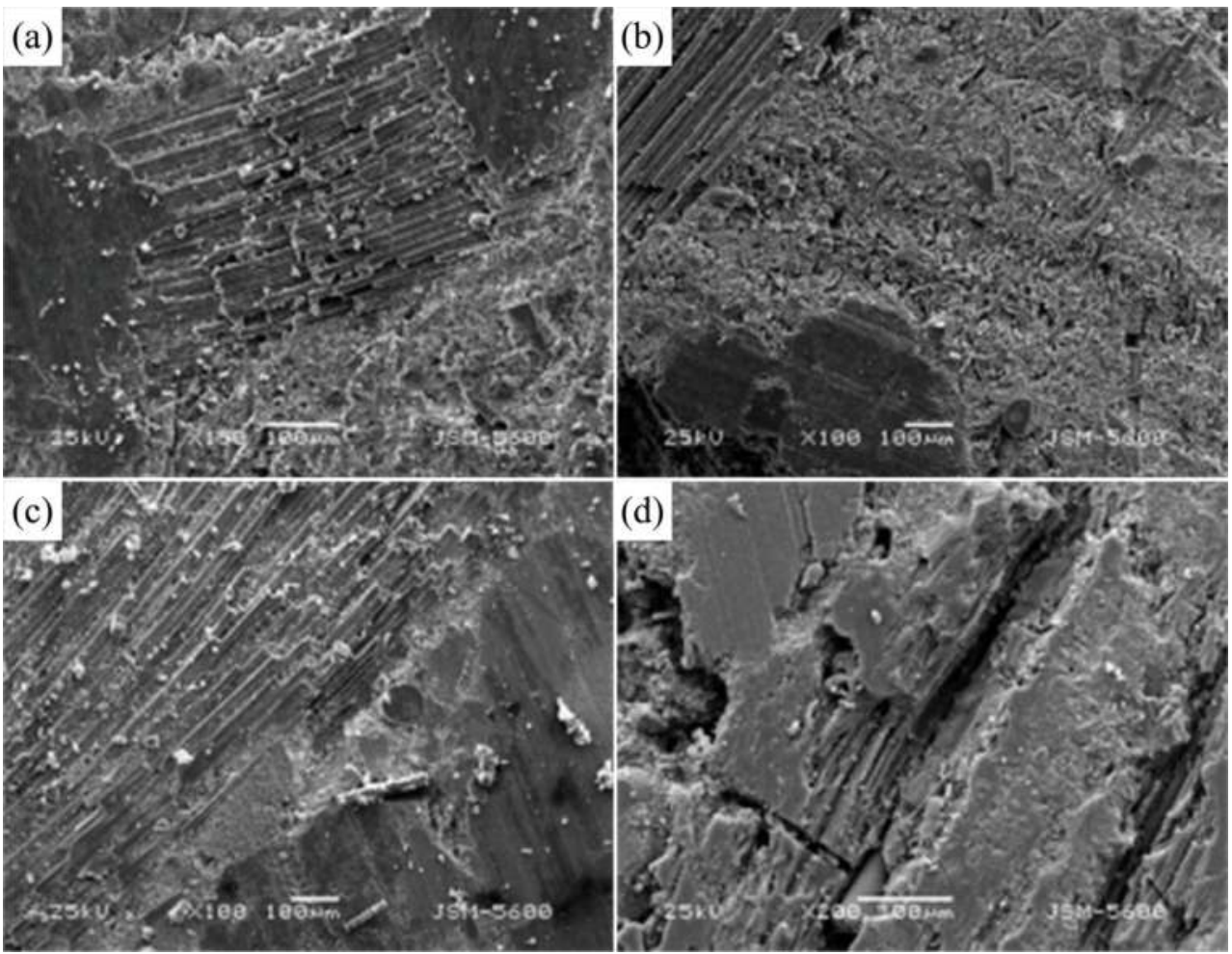

Figure 13. Surface morphologies of the BFRFMs with bamboo fibers of (a) 3 wt.\%; (b) 6 wt.\%; (c) 9 wt.\%; and (d) 12 wt.\%. 

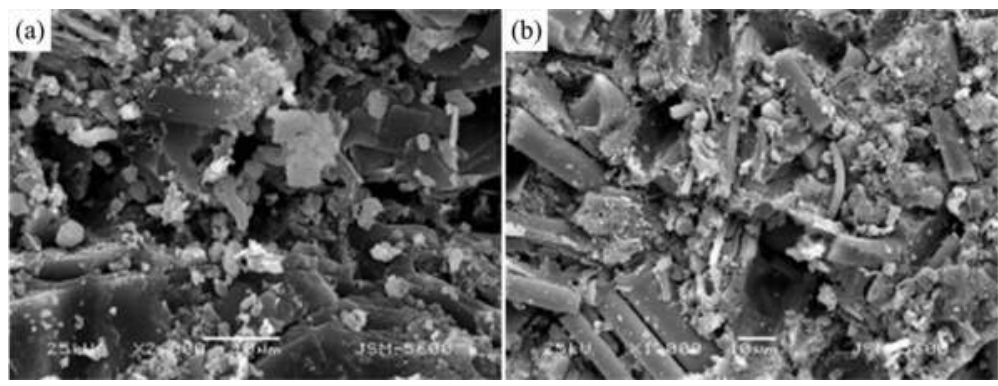

Figure 14. Morphologies of the groove and voids of the BFRFMs with bamboo fibers of (a) 3 wt. \%; and (b) 6 wt. $\%$.

fiber formed under the friction force and the glass fibers did not separate from the matrix completely. It illustrated that the glass fibers were firmly bound with the matrix. Graphite and some particles that carbonized existed on the friction surface, so part of the friction surface was very smooth and easily deformed under friction force and shear force. Therefore, wear resistant surface was formed, and the friction coefficient and wear rate were decreased. Meanwhile, the carbonized fiber can repair the scratch and shallow pits on the worn surface, so the adhesive wear was decreased to some extent [30,31], and the worn surface is relatively smooth. The grooves or voids (Figure 14) formed after the carbonization of the fibers reduced the noise and adhere to wear debris on the wear surface of friction materials [32].

\section{Conclusion}

a. Dry sliding wear of bamboo ( $P$. pubescens) stem is dependent upon the normal load, the sliding velocity, and the cellulose fiber (vascular bundle), and orientation with respect to the rubbing surface. The wear volume of bamboo increases with the crease of the normal load and sliding velocity. Normal-oriented specimens exhibit better wear resistance than paralleloriented ones, and the outside surface layer has better wear resistance than the inner layer.

b. Material transfer phenomena from bamboo to the counterface occur for three types of bamboo specimens. The predominant wear mechanisms are adhesion, microcracking, and microploughing under low load at low velocity, and microploughing-microcutting under high load for $\mathrm{P}_{\mathrm{S}}$-type specimens. The main wear mechanisms of $\mathrm{P}_{\mathrm{I}}$-type specimens are also adhesion, and particularly microcracking and microploughing-microcutting. The wear of $\mathrm{N}$-type specimens is mainly due to adhesion and microcracking, and the matrix tissue shows certain wear resistance.

c. The friction coefficients of friction materials containing 3, 6, and $9 \mathrm{wt} . \%$ bamboo fibers increased with increase of the test temperature, whereas the friction materials containing 12 wt. \% bamboo fibers decreased. 
d. The wear rates were decreased with the increase of bamboo fibers content when the content of bamboo fibers of friction materials was lower than $3 \mathrm{wt} . \%$; the wear rate increased with increase of bamboo fibers content when the bamboo fibers content of friction materials was higher than 3 wt.\%.

e. The bamboo fibers improved the friction performances of fiction materials. The grooves or voids formed after the carbonization of the fibers reduced the noise and adhere to wear debris on the wear surface of friction materials.

\section{Acknowledgements}

This study was supported by National Natural Science Foundation of China (Grant No. 51475205), by Jilin Province Science and Technology Development Plan Item (Grant No. 20150519022JH), by China-EU H2020 FabSurfWAR project (Grant Nos. S2016G4501 and 644971), by Special Foundation of National Key R\&D Program of China (2016YFD0701601), and by Supporting Program of "the twelfth five-year-plan" in national science and technology in rural areas of China (Grant No. 2014BAD06B03-01). Parts of this chapter are reproduced from authors' recent conference publication, work etc. [29, 32].

\section{Author details}

Yunhai Ma ${ }^{1,2}$, Yucheng Liu ${ }^{1,3}$ and Jin Tong ${ }^{1,2 *}$

*Address all correspondence to: jtong@jlu.edu.cn

1 Key Laboratory of Bionic Engineering (Ministry of Education, China), Jilin University (Nanling Campus), Changchun, China

2 College of Biological and Agricultural Engineering, Jilin University (Nanling Campus), Changchun, China

3 Editorial Department of Journal of Bionic Engineering, Jilin University (Nanling Campus), Changchun, China

\section{References}

[1] Lakkad C, Patel JM. Mechanical properties of bamboo, a natural composite. Fibre Science and Technology. 1981;14:319-322

[2] Godbole V S, Lakkad SC. Effect of water absorption on the mechanical properties of bamboo. Journal of Materials Science Letters. 1986;5:303-304

[3] Li S, Zhou B, Zheng Z, Zeng Q. A fine-scale bionic model for composite materials. Chinese Journal of Materials Research. 1991;5:542-547 
[4] Yakou T, Sakamoto S. Abrasive properties of bamboo. Japanese Society of Tribologists. 1993;38:491-497

[5] Tong J, Ren LQ, Li JQ, Chen BC. Abrasive wear behaviour of bamboo. Tribology International. 1995;28:323-327

[6] Bijwe J. Composites as friction materials: Recent development in non-asbestos fiber reinforced friction materials - a review. Polymer Composites. 1997;18:378-396

[7] Xiao G, Zhu Z. Brake materials development by using DOE/RSM and artificial neural network. Tribology International. 2010;43:218-227

[8] Hong US, Jung SL, Cho KH, Cho MH, Kim SJ, Jang H. Wear mechanism of multiphase brake materials with different phenolic resin matrices. Wear. 2009;266:739-744

[9] Almaslow A, Ratnam CT, Ghazali MJ, Talib RJ, Azhari CH. Effects of electron-beam and sulfur crosslinking of epoxidized natural rubber on the friction performance of semimetallic friction materials. Composites Part B: Engineering. 2013;54:377-382

[10] Cho MH, Ju J, Kim SJ, Jang H. Tribological properties of solid lubricants (graphite, $\mathrm{Sb}_{2} \mathrm{~S}_{3^{\prime}}$ $\mathrm{MoS}_{2}$ ) for automotive brake materials. Wear. 2006;260:855-860

[11] Kukutschová J, Roubíček V, Mašláň M, Jančík D, Slovák V, Malachová K, et al. Wear performance and wear debris of semimetallic automotive brake materials. Wear. 2010;268:86-93

[12] Chang QX, Wang KS, Zhao HJ. The friction and wear properties of short Carbon/CNT/ PA6 hybrid composites under dry sliding conditions. International Journal of Polymeric Materials. 2013;62:540-543

[13] Yousif BF, Nirmal U, Wong KJ. Three-body abrasion on wear and frictional performance of treated betel $\geq$ nut fibre reinforced epoxy (T-BFRE) composite. Materials \& Design. 2010;31:4514-4521

[14] Hashmi SAR, Dwivedi UK, Chand N. Graphite modified cotton fibre reinforced polyester composites under sliding wear conditions. Wear. 2007;262:1426-1432

[15] Eleiche AM, Amin GM. The effect of unidirectional cotton fiber reinforcement on the friction and wear characteristics of polyester. Wear. 1986;112:67-78

[16] Ma YH, Liu YC, Ma SS, Wang HB, Shang WB, Gao ZH, et al. Friction and wear properties of dumbbell-shaped jute fiber-reinforced friction materials. Journal of Applied Polymer Science. 2014;131. DOI: 10.1002/app.40748

[17] Liu L, Wang Q, Xia Z, Yu J, Cheng L. Mechanical modification of degummed jute fibre for high value textile end uses. Industrial Crops and Products. 2010;31:43-47

[18] Chand N, Dwivedi UK. Effect of coupling agent on abrasive wear behaviour of chopped jute fibre-reinforced polypropylene composites. Wear. 2006;261:1057-1063

[19] Chen Y, Sun LF, Ovidiu C, Ioan N, Yachmenev V, Mary W. Kenaf/ramie composite for automotive headliner. Journal of Polymers and the Environment. 2005;13:107-114 
[20] Wu CR, Jia SK, Chen RY, Huang Z, Zhai SF, Feng YH, et al. Composites of sisal fiber/ polypropylene based on novel vane extruder: Effect of interface and damage on mechanical properties. Journal of Reinforced Plastics and Composites. 2013;32:1907-1915

[21] Mohan TP, Kanny K. Water barrier properties of nanoclay filled sisal fiber reinforced epoxy composites. Composites: Part A. 2011;42:385-393

[22] Liu Q, Hughes M. The fracture behavior and toughness of woven flax fiber reinforced epoxy composites. Composites: Part A. 2008;39:1644-1652

[23] El-Tayeb NSM. A study on the potential of sugarcane fibers/polyester composite for tribological applications. Wear. 2008;265:223-235

[24] Paramesaran N, Liese W. On the fine structure of bamboo fibers. Wood Science and Technology. 1976;10:231-246

[25] Fuentes CA, Tran LQN, Dupont-Gillain C, Vanderlinden W, De Feyter S, Van Vuure AW, et al. Wetting behaviour and surface properties of technical bamboo fibers. Colloids and Surfaces A: Physicochemical and Engineering Aspects. 2011;380:89-99

[26] Dieu T, Liem N, Mai T, Tung N. Study on fabrication of BMC laminates based on unsaturated polyester resin reinforced by hybrid bamboo/glass fibers. JSME International Journal Series A. 2004;47:570-573

[27] Nahar S, Khan RA, Dey K, Sarker B, Das AK, Ghoshal S. Comparative studies of mechanical and interfacial properties between jute and bamboo fiber-reinforced polypropylenebased composites. Journal of Thermoplastic Composite Materials. 2012;25:15-32

[28] Ma YH, Liu YC, Menon C, Tong J. Evaluation of wear resistance of friction materials prepared by granulation. ACS Applied Materials \& Interfaces. 2015;7:22814-22820

[29] Tong J, Arnell RD, Ren LQ. Dry sliding wear behaviour of bamboo. Wear. 1998;221:37-46

[30] Essabir H, Achaby MEI, Hilali EIM, Bouhfid R, Qaiss A. Morphological, structural, thermal and tensile properties of high-density polyethylene composites reinforced with treated Argan nut shell particles. Journal of Bionic Engineering. 2015;12:129-141

[31] Wen S, Li K, Song Q, Shan Y, Li Y, Li H, Ma H. Enhancement of the oxidation resistance of $\mathrm{C} / \mathrm{C}$ composites by depositing $\mathrm{SiC}$ nanowires onto carbon fibers by electrophoretic deposition. Journal of Alloys and Compounds. 2015;618:336-342

[32] Ma YH, Shen SL, Tong J, Ye W, Yang YZ, Zhou J. Effects of bamboo fibers on friction performance of friction materials. Journal of Thermoplastic Composite Materials. 2013;26:845-859 